\title{
„Widziałaś już te filmiki z wanny, które ci wysłałam?" Audiowizualne historie codzienności w czasie pandemii
}

Pomysł na projekt narodził się podczas lockdownu, który przyzwalał, ale i wymuszał częste bywanie na portalach społecznościowych. Stały się one kanałem umożliwiającym nie tylko komunikację i utrzymywanie kontaktu, ale i aktywności, które dotąd odbywały się offline. Dość szybko pojawił się ruch rozpowszechniony hasztagiem \#stayathome, który zachęcał do pozostawania w domu oraz potrzebę zachowania dystansu, by nie narażać siebie i innych.

Hasztag jest promocją, który miała stworzyć atrakcyjną wizję pozostania $\mathrm{w}$ domu - przenosząc sferę publiczną do strefy online. Nie tylko wiele organizacji, instytucji kulturowych i indywidualnych inicjatyw przeniosło swoje programy na platformy społecznościowe. Przez czas lockdownu można było także podglądać prywatne osoby, znajomych, którzy oddawali się gotowaniu, układaniu puzzli, głaskaniu zwierzaków domowych, przesadzaniu roślin, rozwijaniu nowego hobby albo zwykłemu odpoczywaniu. Oczywiście nie można nie zauważyć, że ten swoisty przywilej dotyczył przede wszystkim klasy średniej, która nie pracowała w sektorze usługowym oraz na pierwszej linii frontu (w służbie zdrowia, ochronie bezpieczeństwa publicznego, na poczcie, w aptece lub sklepie spożywczym). Dynamiczna sytuacja wynikająca $z$ narzucanych ograniczeń i obostrzeń w wielu przypadkach wymusiła konieczność nowych decyzji i poniekąd przewartościowania dotychczasowego stylu życia (często dotyczyło to konieczności przeprowadzki, wyprowadzenia się z domu, rezygnacji z zaplanowanych działań, transformacji stanowiska pracy lub firmy). Wdrażanie się w nowe sytuacje nierzadko powodowało wiele emocji związanych z przedłużającym się czasem oczekiwania na normalność. 
Zmiana tempa przejawiła się w doświadczeniu życia codziennego, które na skutek pandemii nagle zastygło $\mathrm{w}$ bezruchu Mimo że walka $\mathrm{z}$ rozprzestrzeniającym się wirusem była i jest dynamiczna, to jednak wiele rzeczy i spraw uległo zawieszeniu, panujący wirus wycofał ludzi do domów i wymusił budowanie dystansu nie tylko fizycznego, ale i społecznego. Przez kilka pierwszych tygodni pandemii puste ulice, zamknięte sklepy, pustki w komunikacji miejskiej stanowiły krajobraz codzienności. Wydawało się nawet, że świat po prostu chwilowo odpoczywa W rzeczywistości było jednak inaczej. Z jednej strony globalna gospodarka zatrzymała się, zmierzając do ekonomicznego kryzysu, z drugiej codziennością były obrazy przepełnionych szpitali i uczucie narastającej kontroli. W czasie izolacji jedynym oknem na świat zewnętrzny były spersonalizowane media społecznościowe, które przedstawiały kontrastowe rytmy życia społecznego. Dodatkowo liczba przyjmowanych dziennie wiadomości powodowała dezorientację. Kolektywnie narastające niepokoje dotyczące niepewnej przyszłości oraz zagrożenie zdrowia wydawały się nie korespondować ze zdjęciami wrzucanymi przez znajomych, które rejestrowały spokojne życie w zaciszu własnego domu. Co więcej, codzienność ograniczona do czterech ścian była nazbyt zwykła i nudna, aby o niej opowiadać. Użytkownicy mediów społecznościowych prześcigali się więc w uatrakcyjnianiu swoich raportów z codzienności, jakimi dzielili się ze światem. Mnie jednak zainteresowały te obrazy i opowieści, które wydawały się nieatrakcyjne dla publicznego udostępnienia, zwracające uwagę na cielesne doświadczenia i przeżywane emocje w zwykłej codzienności.

Rozmyślając nad formami opowiedzenia o wspomnianych - a często pomijanych - doświadczeniach, skupiłam się nad zagadnieniami dotyczącymi tempa życia codziennego, praktyk związanych z pozostaniem w domu oraz odczuciami związanymi z pandemią. Zaangażowanie się w każde z tych zagadnień miało dać ramy, w których mogłam się poruszać podczas całego procesu razem z zaproszonymi do współpracy przyjaciółkami: Dorotą, Kamilą oraz Patrycją. Szeroka i swobodna perspektywa dawała pole do nie tylko manewru, w sensie realizacji projektu, ale i do możliwości negocjacji z moimi partnerkami. We wstępnym założeniu istotną dla mnie kwestią była wolność $w$ interpretacji tematu oraz formy ekspresji. Dorota, Kamila i Patrycja wybrały formy i media, którymi najwygodniej było im się posługiwać, pracując nad własnymi historiami.

Nasza współpraca skupiała się na zbieraniu zdjęć, filmów rejestrujących indywidualne historie mieszkanek Łodzi, Ossowic i Wrocławia na tle dynamicznych zmian społecznych. Trzy tygodnie trwania projektu, na przełomiemarca i kwietnia 2020 r., okazały się etapem, który dawał pierwszeństwo przeżywaniu aktualnej sytuacji, a nie kwestiom estetycznym. Wspólne rozmowy nie tylko polegały na dzieleniu się wrażeniami, ale również uwydatniały silną potrzebę wzajemnego wsparcia, gdyż nieoczywistość przyszłości i stan zamknięcia w domu sprawiały, że moja rola badaczki musiała być negocjowana z rolą przyjaciółki, z którą dzieli się wątpliwości czy skrywane niepokoje. W ostateczności, jak mi 
się wydaje, w trakcie pracy nad projektem każda z nas zdołała się w pewien sposób zdystansować do sytuacji, w której się znalazła. Przegadywanie, negocjowanie i interpretowanie wizualnego materiału opowiadającego o codzienności w jakiś sposób pozwoliło także na dostrzeżenie niepokojów i lęków.

Dopełnieniem dokumentacji wizualnej były długie rozmowy, które prowadziłyśmy wspólnie z Dorotą, Kamilą i Patrycją. Efektem naszej współpracy są krótkie formy audiowizualne wykorzystujące zebrany materiał z dokumentacji codzienności oraz fragmenty rozmów. Efekt końcowy współpracy można obejrzeć pod linkiem:

https://www.youtube.com/playlist?list=PL8nL9-gkHVfOeK4OkbmGGvOhyXj_vluAb 